\title{
Mid-Holocene Hunter-Gatherers 'Gaomiao' in Hunan, China: The First of the Two-layer Model in the Population History of East/Southeast Asia
}

\author{
Hirofumi Matsumura, Hsiao-chun Hung, Nguyen Lan Cuong, \\ Ya-feng Zhao, Gang He and Zhang Chi
}

Gaomiao, the eponymous archaeological site of the Gaomiao Culture (ca. 7500-5500 BP) has produced evidence of a unique hunter-gatherer society in Hunan Province, China, that produced fine decorated pottery. The human remains unearthed from this site provided an excellent opportunity to assess phenotypic and biological relationships between the Gaomiao and prehistoric and modern human populations that have inhabited East/Southeast Asia over the past ca. 10,000 years through cranial morphometrics. The assessment of morphometric affinity presented here addresses the peopling of East Asia, particularly in the context of the 'two-layer' hypothesis describing the population history of this region. The results suggest that the Gaomiao skeletons inherited genetic signatures from early colonising populations of Late Pleistocene southern Eurasian origin to a certain extent, and might share a common ancestry with present-day Australian Aboriginal and Melanesian people.

\section{Introduction}

The study of the population history of East Asia remains complex due to various migration processes and intermixing of populations throughout prehistory, poor archaeological sample sizes and limited radiometric dating. In general terms, East Asia is thought to have been originally inhabited by (to use the classic term) 'Mongoloid' peoples from the Late Pleistocene onwards. In the Late Pleistocene and early Holocene of Southeast Asia, several sets of human remains exhibit Australo-Melanesian characteristics, and it has been argued that an indigenous population possessing this morphological form occupied Southeast Asia. These skeletal data demonstrated significant genetic discontinuity between pre- and post-agricultural populations, suggesting that dramatic agriculturally driven demic expansion occurred in Mainland Southeast Asia (MSEA) beginning in the Neolithic period (see Matsumura and Zuraina 1999; Matsumura and Hudson 2005; Matsumura 2006; Matsumura et al. 2008a, 2008b, 2011a, 2011b; Oxenham et al. 2011; Matsumura and Oxenham 2013a, 2013b, 2014, 2015). This population history scenario for Southeast Asia is known as the 'two-layer' or 'immigration' model, a scenario of human population movement that was first postulated in the middle of the last century (q.v., Jacob 1967). 
Given this perspective overview in MSEA, problems have arisen as to whether pre-existing indigenous hunter-gatherers in more northerly East Asia, as well as early settlers of Southeast Asia, were genealogically akin to present-day Australian Aboriginal and Melanesian populations, whether there was an agriculturally driven mass population movement, and whether they were replaced by the migrating agriculturalists who shared a suite of features with Northeast Asians (archetypically referred as 'Mongoloid').

The discovery of human skeletal remains at the site of Gaomiao provides a rare opportunity to apply cranial morphometrics to compare the skeletal affinities of these hunter-gatherers with other prehistoric and modern human populations in the region, and to evaluate the strengths of the 'two-layer' hypothesis in Mainland East Asia. This paper introduces the skeletal morphology of Gaomiao and presents results pertaining to the cranial affinity, based on craniometric data, in comparison with early and modern population samples from the area covering East/Southeast Asia and the Western Pacific.

\section{Archaeological background and context}

Gaomiao is located on the northern bank of the Yuan River in Yanli Village of Chatou in Hongjiang City (formerly named as Qianyang County) in Hunan Province (Figure 4.1). The site was excavated three times (in 1991, 2004 and 2005) by the Cultural Relics and Archeological Research Institution in Hunan Province (He 2006a, 2006b). It consists of large shell mounds produced by the human discard of abundant freshwater molluscs, and aquatic and terrestrial fauna, including some pigs identified as domestic (He 2006a). Evidence for agriculture is currently sparse with no rice phytoliths or macrobotanicals having been identified so far. Rice grain impressions have been identified in three sherds and rice husk in another at Gaomiao, but the source of this pottery is unclear (Gu and Zhao 2009). Overall, it is considered that the site occupants were hunter-gatherers rather than agriculturalists (He 2006a). A unique feature of the Gaomiao site is its pottery decoration. Despite the deep antiquity, the early pottery forms exhibit very fine decoration, including cord impressions and dentate stamping, the latter forming animal faces, phoenixes, waves, trapezoids, circles and band-like motifs on the surfaces of vessels, jars, plates and bowls. Furthermore, it is noteworthy that the pottery with the phoenix motif probably embodied certain religious beliefs (He 2006a, 2006b). This finding has led archaeologists to realise the mutual and remote influences of cultural and artistic accomplishments from Gaomiao on various later regional cultures in ancient China. Gaomiao appears to have been a unique hunter-gatherer subsistence society associated with a well-developed material culture (Zhang and Hung 2012; Figure 4.2). 


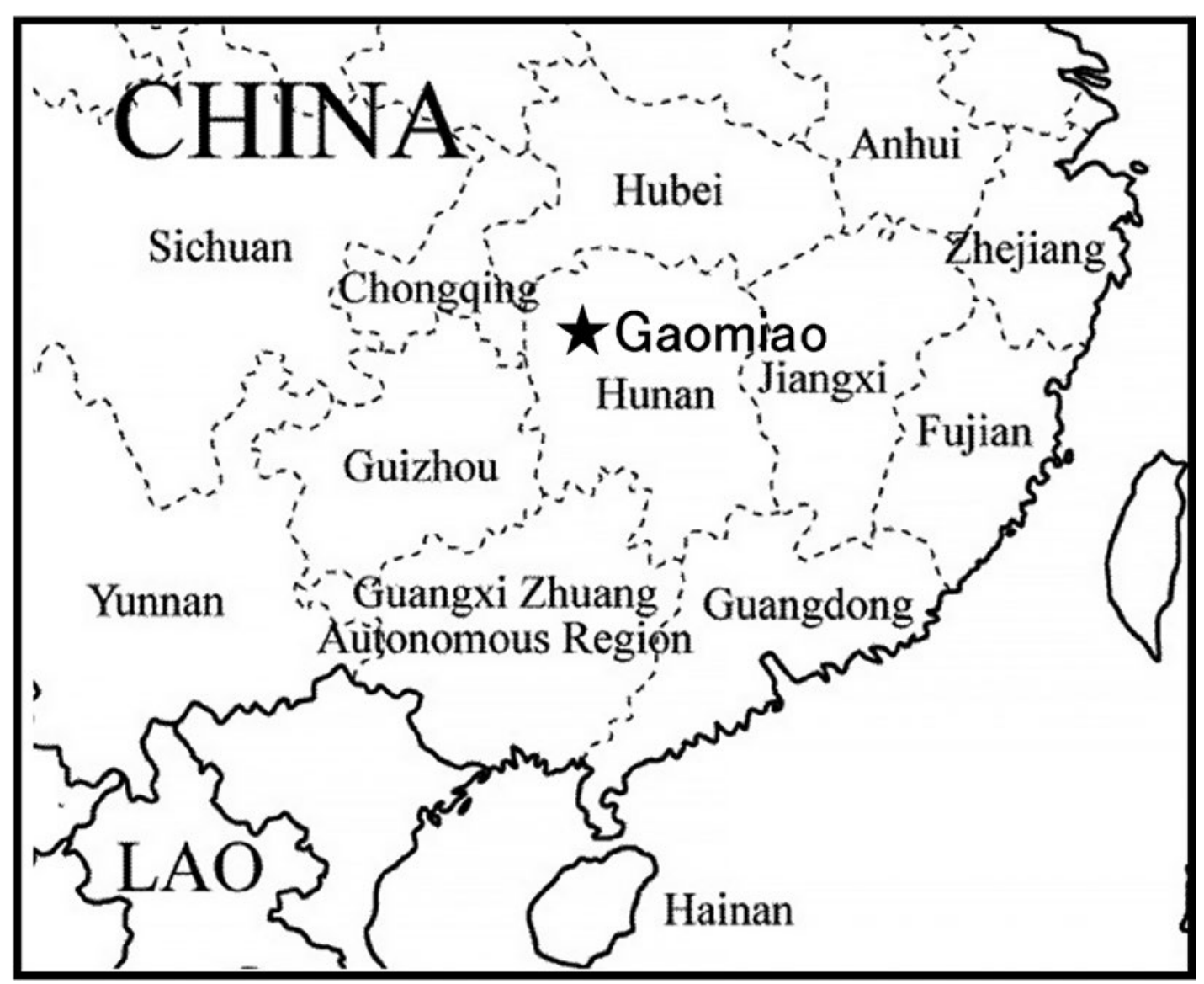

Figure 4.1 The locality of Gaomiao in southern China.

Source: H. Matsumura.

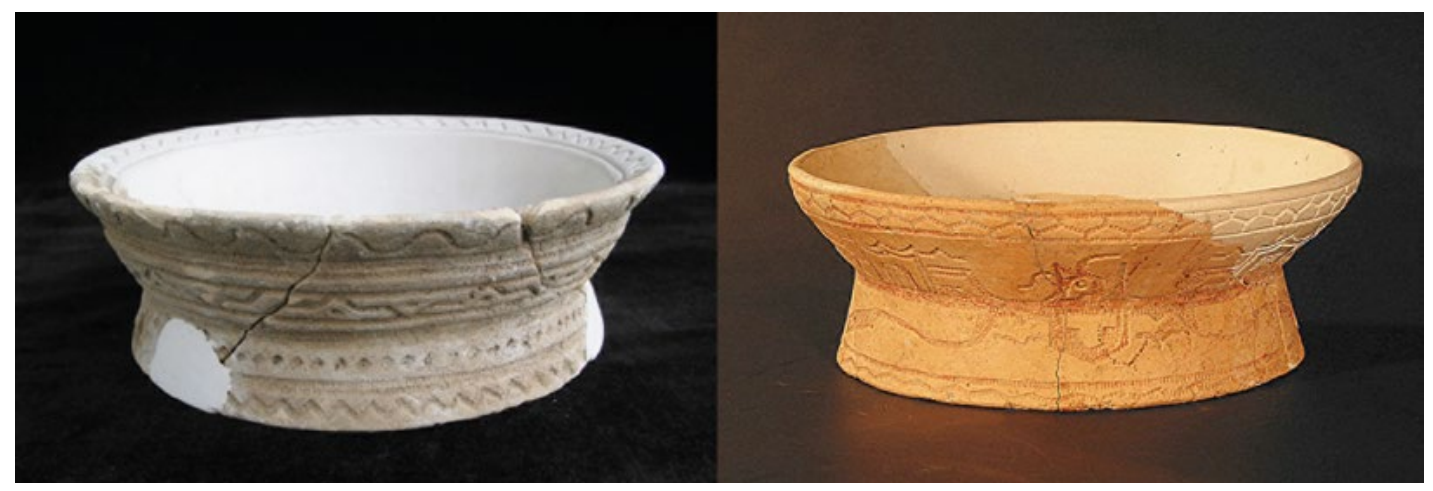

Figure 4.2 The representative pottery from Gaomiao.

Source: $\mathrm{G}$. He.

From the Gaomiao site, two major burial assemblages were exposed, containing more than 30 burials. The earliest individuals were interred in a flexed position without grave goods (see Figure 4.3), whereas in the later-phase burials shifted to the extended type with abundant grave goods, including pottery and jade. The later burial sequence, though lacking Oryza sativa rice, was likely influenced by a neighbouring agricultural society; for example, the Daxi culture (ca. 6500-5000 BP) around the Dongting Lake area in Hunan Province. Nevertheless, only three inhumation burials produced well-preserved skeletal remains, all of which were found in the flexed position of the earlier sequence. 


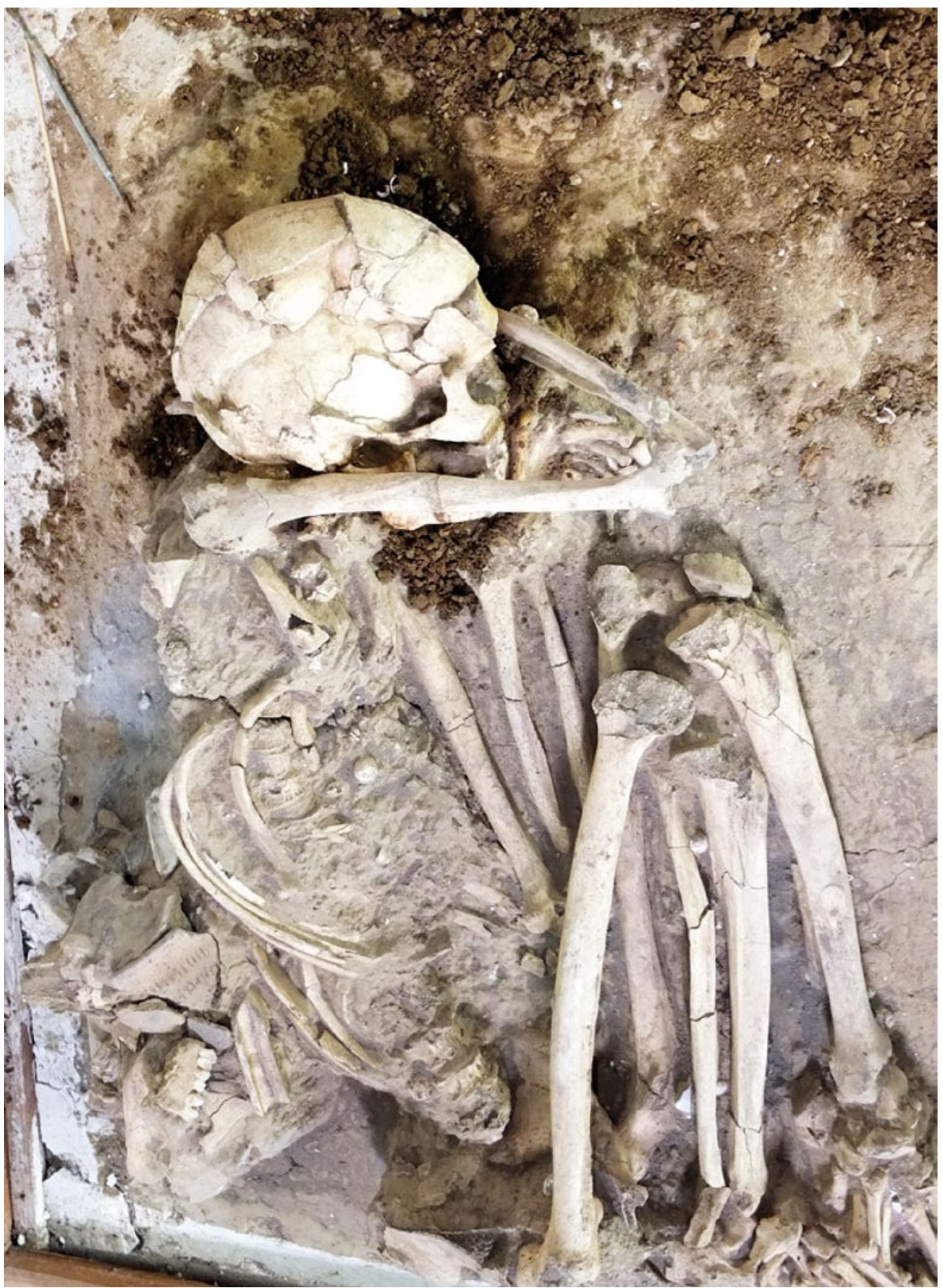

Figure 4.3 The human skeleton M-02 from Gaomiao.

Source: H. Matsumura.

These three individuals provided AMS carbon-14 dates based on tooth dentine collagen, of approximately $6500 \mathrm{BP}$ (see Table 4.1, dated by the Beta Analytic laboratory in the USA). 
Table 4.1 Gaomiao radiocarbon dating results gained from this study.

\begin{tabular}{|l|l|l|l|l|l|}
\hline $\begin{array}{l}\text { Beta Sample } \\
\text { No. }\end{array}$ & Human remains & $\begin{array}{l}\text { Measured radiocarbon } \\
\text { age (years BP) }\end{array}$ & $\begin{array}{l}{ }^{13} \mathrm{C} /{ }^{12} \mathrm{C} \text { ratio } \\
(\% 0)\end{array}$ & $\begin{array}{l}\text { Conventional age } \\
\text { (years BP) }\end{array}$ & $\begin{array}{l}\text { Calibrated years BP } \\
(2-\text { Sigma) }\end{array}$ \\
\hline 328354 & $\begin{array}{l}\text { Gaomiao M-01 } \\
\text { child }\end{array}$ & $5690 \pm 40$ & -20.8 & $5760 \pm 40$ & $\begin{array}{l}6659-6464(94.6 \%) \text { or } \\
6459-6453(0.8 \%)\end{array}$ \\
\hline 328353 & $\begin{array}{l}\text { Gaomia0 M-02 } \\
\text { adult }\end{array}$ & $5500 \pm 40$ & -19.2 & $5600 \pm 40$ & $6452-6300(95.4 \%)$ \\
\hline 333225 & $\begin{array}{l}\text { Gaomia M-20 } \\
\text { unknown age }\end{array}$ & $5680 \pm 30$ & -12.6 & $5880 \pm 30$ & $\begin{array}{l}6777-6764(3.1 \%) \text { or } \\
6752-6640(92.3 \%)\end{array}$ \\
\hline
\end{tabular}

Source: H.-c. Hung.

\section{Cranial preservation and morphological remarks}

Of the three skeletal individuals unearthed at Gaomiao, one (no. M-01) was a child around 1214 years old, currently exhibited at the Haihua (懷化) City Museum. Another child specimen, numbered M-20, is very fragmentary and housed at the Cultural Relics and Archeological Research Institution in Changsha City (長沙市). The M-02 skeleton alone, currently displayed at the Hongjiang City (洪江市) Museum, is of an adult individual in a good state of preservation. In this study, we reconstructed only this adult cranium for morphometric analysis.

The M-02 individual was estimated to be a mature male over 60 years old based on the extent of tooth attrition, antemortem tooth loss, cranial suture closures, and severity of osteoarthritis. Figure 4.4 displays various aspects of his reconstructed skull. Although the cranium had fragmented through in situ crushing, almost all parts of the specimen could be reconstructed. The greater and lesser wings of the sphenoid bone are missing from the cranial vault.

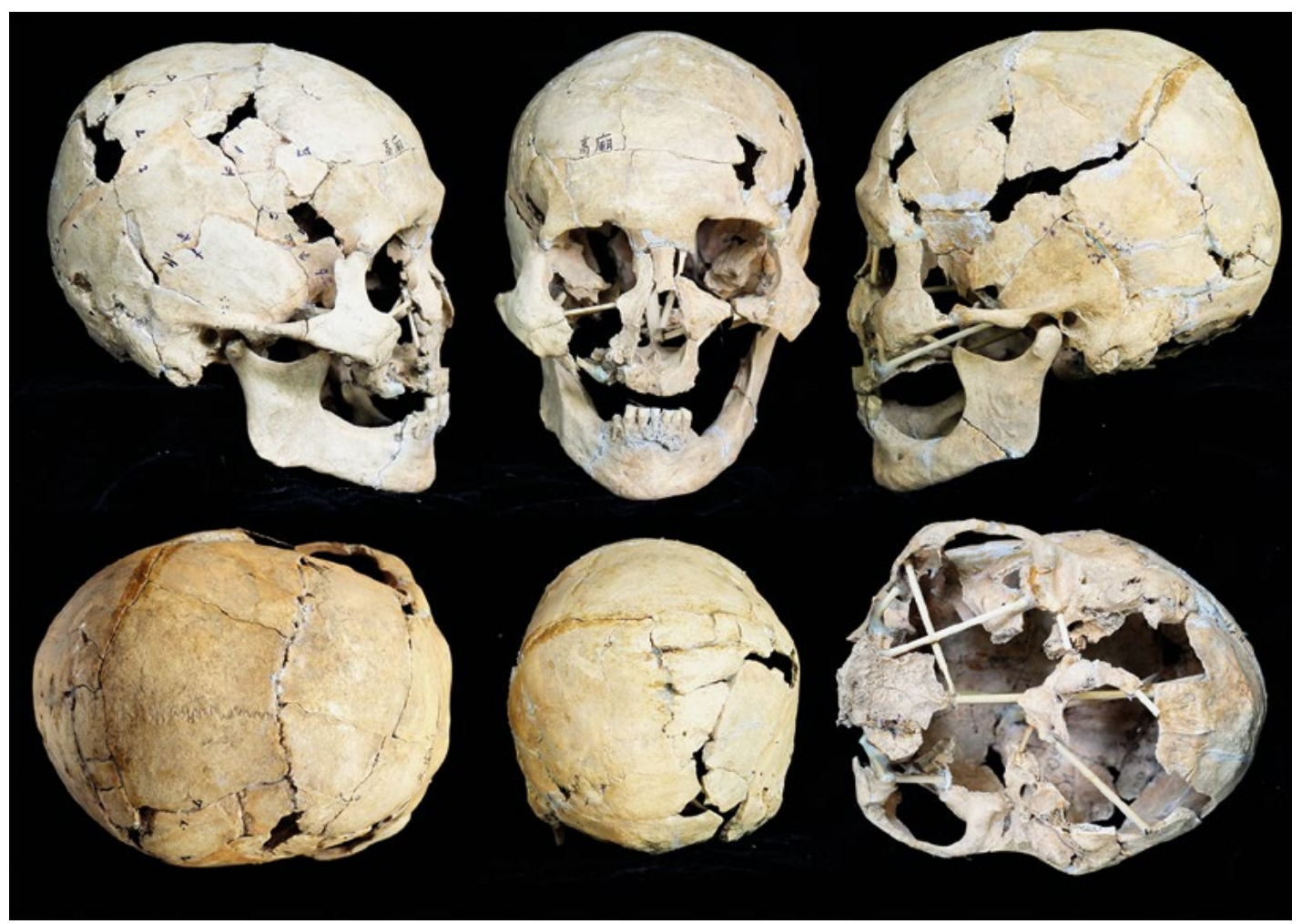

Figure 4.4 The reconstructed skull of M-02 from Gaomiao.

Source: H. Matsumura. 
The face of the skeleton lacks some parts of the maxilla, and the ethmoid and lachrymal bones, and the inferior conchae and vomer, which together form the inside of the orbits and the inner portion of the nasal cavity.

The cranial shape is ovoid in superior view and the vault is mesocephalic (cranial index 79.1). The external occipital protuberance is well protruding, and the superior nuchal line is clearly defined with a well-developed nuchal plane, indicating that this person possessed strong neck muscles. The temporal line, to which the temporal muscles attach, is marked in the frontal region but becomes weak towards the posterior end of the temporal bones. The glabella region is large and prominently protruding compared with the majority of modern East Asian males, although the supercilliary arch is relatively flat. The frontal bone leans well back, clearly exhibiting male characteristics. The facial skeleton is low and wide (upper facial index 47.1, upper facial height was estimated as described in the section on the recoding system for cranial measurements). The orbital margins are straight at the superior line, and the nasal root is moderately concave. The coronal, sagittal, and lambdoidal sutures are completely fused ecto- and endocranially. The mandible expresses alveolar prognathism. Frontal nerve incisures and superior orbital foramina are absent on both sides of the frontal bone. The supramastoid crest is weak, and the mastoid process is moderate in size.

The mandibular body is relatively small and low, while the muscle attachments are moderately developed. The mental eminence is weakly projecting. The mylohyoid line is well angulated. The mandibular ramus is wide with a weakly concave mandibular notch. The preangular incisula is shallow and the lateral prominence is small at the gonial angle. The attachment area of the medial pterygoid muscles is well developed.

The following teeth are present in the maxilla and mandible.

\begin{tabular}{llllllll|llllllll}
$/$ & $/$ & $x$ & $x$ & $/$ & $x$ & $x$ & $x$ & $x$ & $x$ & $x$ & $/$ & $/$ & $/$ & $M 2$ & $/$ \\
\hline$x$ & $x$ & $x$ & $x$ & 0 & 0 & 12 & 11 & 11 & 12 & $C$ & $x$ & $x$ & $x$ & $x$ & $x$
\end{tabular}

$\mathrm{X}=$ tooth lost antemortem and alveolus remodelled

$0=$ tooth lost post-mortem and alveolus not remodelled

/ = tooth lost post-mortem and alveolus damaged

The maxilla lacked al most all teeth, and the mandible had also lost most posterior teeth antemortem. The occlusal surfaces of the remaining teeth were heavily worn, with enamel remaining only on the outer rim, the entire occlusal surface of the crown being lost and secondary dentine visible on every tooth. To carry out mitochondrial DNA analysis, the left maxillary second molar was taken out for sampling. 


\section{Recording system for cranial measurements and statistical procedures}

Thirty-two cranial measurements and some representative cranial indices were recorded following Martin's definitions (Bräuer 1988), as given in Table 4.2. The upper facial height and the basionprosthion length are estimated values, as the measurement landmark of the prosthion was missing due to the antemortem loss of maxillary incisors, which eroded the edge of the maxillary alveolar bone. In this study, the prosthion was estimated to be at the point extending $5 \mathrm{~mm}$ from the alveolar margin. This estimation was based on the average height of the missing portion in representative samples such as Jomon and Japanese crania.

Using the data sets of cranial metrics, multivariate statistical procedures were used to explore the population affinities between the Gaomiao sample and ethnically and chronologically different groups. The comparative samples are listed in Tables 4.3 and 4.4 and this summary also includes archaeological specimens from East/Southeast Asia, as well as modern samples from East/Southeast Asia and the Pacific. Similarities in cranial proportions were estimated by Q-mode correlation coefficients (Sneath and Sokal 1973) using the cranial measurements. The cranial data set selected for this calculation were a subset of 16 measurements (Martin's method number: M1, M8, M9, M17, M43(1), M43c, M45, M46b, M46c, M48, M51, M52, M54, M55, M57, M57a), as these were the most commonly available among the comparative samples. The neighbor-net split method (the software package 'Splits Tree Version 4.0' provided by Hudson and Bryant 2006) was applied to the distance matrix of the Q-mode correlation coefficients to aid in the interpretation of inter-sample phenotypic affinities.

Table 4.2 Cranial measurements $(\mathrm{mm})$ and indices for the human skull from Gaomiao site.

\begin{tabular}{|l|c|}
\hline Martin no. and measurement & (mm) \\
\hline 1 Maximum cranial length & 191 \\
\hline 5 Basion-nasion length & 107 \\
\hline 8 Maximum cranial breadth & 151 \\
\hline 9 Minimum frontal breadth & 98 \\
\hline 10 Maximum frontal breadth & 125 \\
\hline 12 Maximum occipital breadth & 125 \\
\hline 17 Basion-bregma height & 151 \\
\hline 29 Frontal chord & 117 \\
\hline 30 Parietal chord & 121 \\
\hline 31 Occipital chord & 107 \\
\hline 40 Basion-prosthion length & 98 \\
\hline 43 Upper facial breadth & 110 \\
\hline 45 Bizygomatic breadth & 153 \\
\hline 46 Bimaxillary breadth & 117 \\
\hline 48 Upper facial height & 72 \\
\hline 51 Orbital breadth & 44 \\
\hline 52 Orbital height & 35 \\
\hline
\end{tabular}

\begin{tabular}{|l|c|}
\hline Martin no. and measurement & (mm) \\
\hline 54 Nasal breadth & 24 \\
\hline 55 Nasal height & 55 \\
\hline 60 Upper alveolar length & - \\
\hline 61 Upper alveolar breadth & - \\
\hline 66 Bigonial breadth & 105 \\
\hline 68 Mandibular length & 81 \\
\hline 69 Symphyseal height & 39 \\
\hline 70 Ramus height & 60 \\
\hline 71 Ramus breadth & 34 \\
\hline 8:1 Cranial index & 79.1 \\
\hline 48:45 upper facial index & 47.1 \\
\hline 43(1) Frontal chord & 104 \\
\hline 43c Frontal subtense & 19.4 \\
\hline 57 Nasal cord & 8.5 \\
\hline 57a Nasal subtense & 1.5 \\
\hline 46b Bimaxillary cord & 119 \\
\hline 46c Nasospinale sabutense & 32.9 \\
\hline
\end{tabular}

Source: H. Matsumura. 


\begin{tabular}{|c|c|c|c|c|c|c|c|c|c|c|c|c|c|c|c|c|c|}
\hline 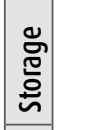 & & 全 & & & $\underline{\underline{T}}$ & 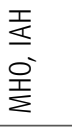 & 年 & 至 & 产 & 覓 & & & & 主 & $\begin{array}{l}\text { 差 } \\
\text { 童 } \\
\text { 吾 }\end{array}$ & 衣 & \\
\hline 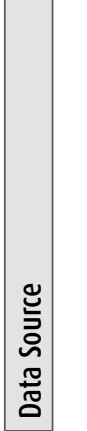 & 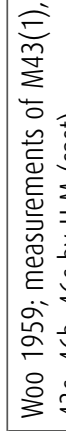 & $\sum_{i}$ & & & $\sum_{i=1}$ & $\sum_{\text {I }}$ & $\sum_{x}$ & 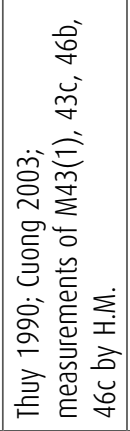 & 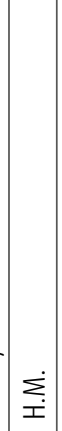 & $\sum_{x}$ & 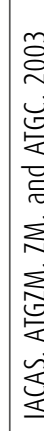 & & 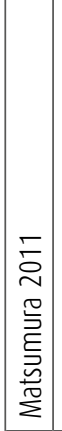 & 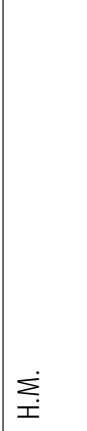 & 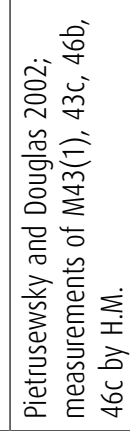 & $\sum_{x}$ & 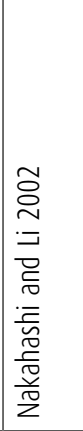 \\
\hline 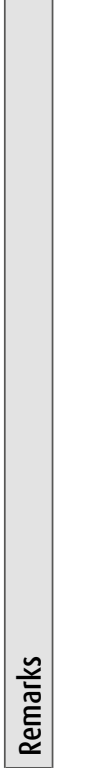 & 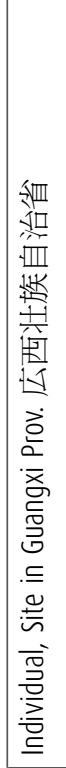 & 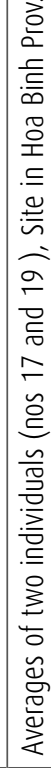 & & & 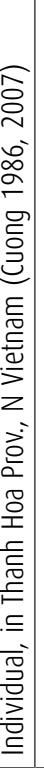 & 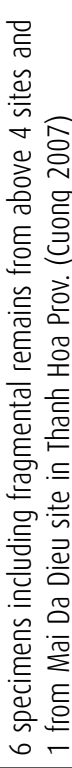 & 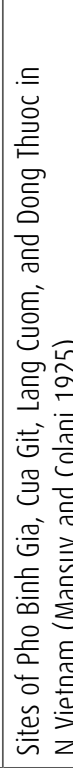 & 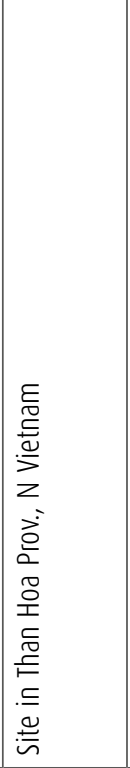 & 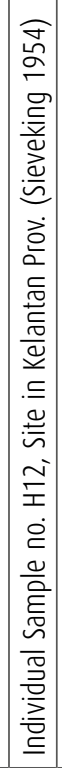 & 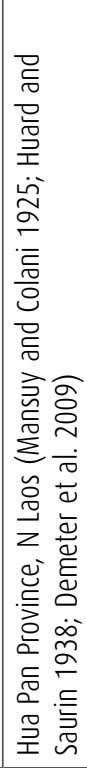 & 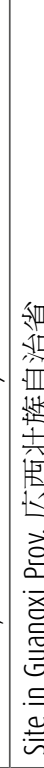 & & 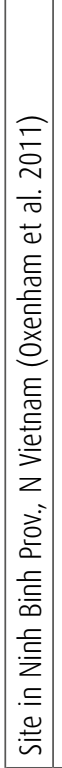 & 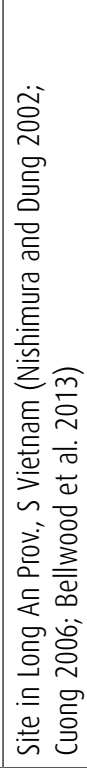 & 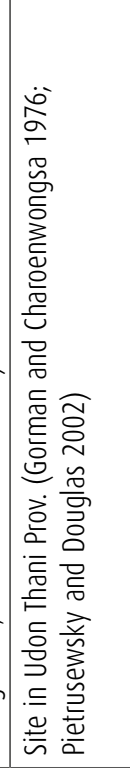 & 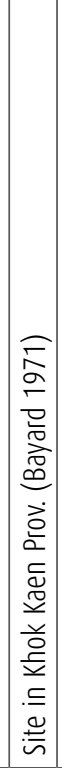 & 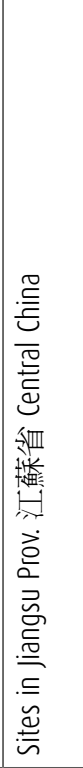 \\
\hline $\begin{array}{l}\stackrel{\overline{0}}{\bar{a}} \\
\bar{\alpha}\end{array}$ & 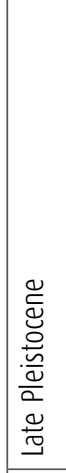 & 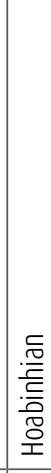 & & & 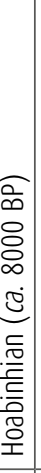 & 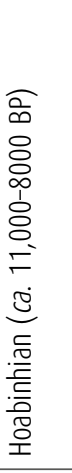 & 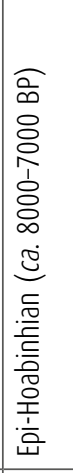 & 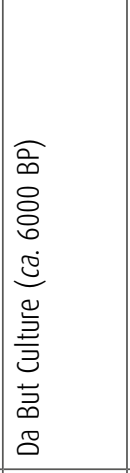 & 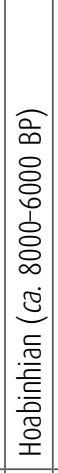 & 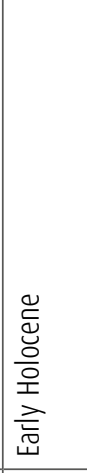 & 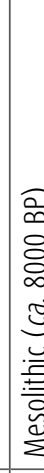 & & 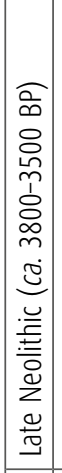 & 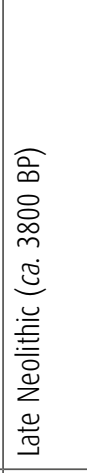 & 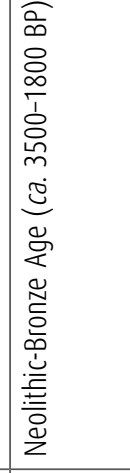 & 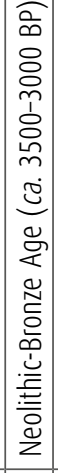 & 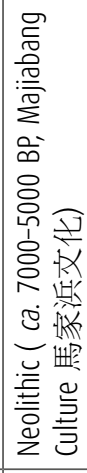 \\
\hline 豙 & 总 & 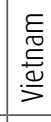 & & & 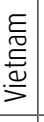 & 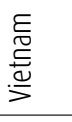 & 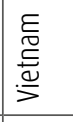 & 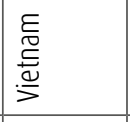 & 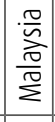 & 察 & 는 & & $\begin{array}{l}E \\
E \\
\stackrel{E}{ \pm} \\
\stackrel{0}{\Xi} \\
\end{array}$ & 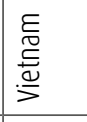 & 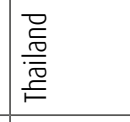 & 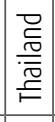 & 疍 \\
\hline \begin{tabular}{|c|c} 
\\
\end{tabular} & 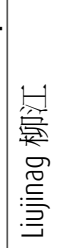 & $\approx$ & & & 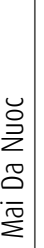 & 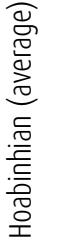 & 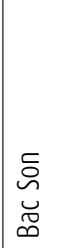 & $\begin{array}{l}0 \\
\text { E } \\
0 \\
\text { c } \\
0\end{array}$ & 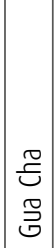 & 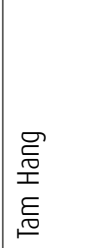 & 道 & 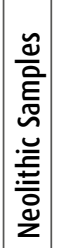 & 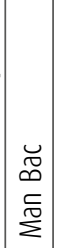 & 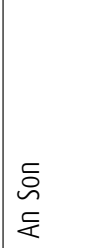 & 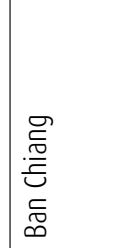 & 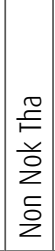 & 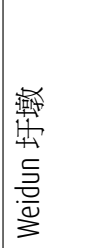 \\
\hline
\end{tabular}




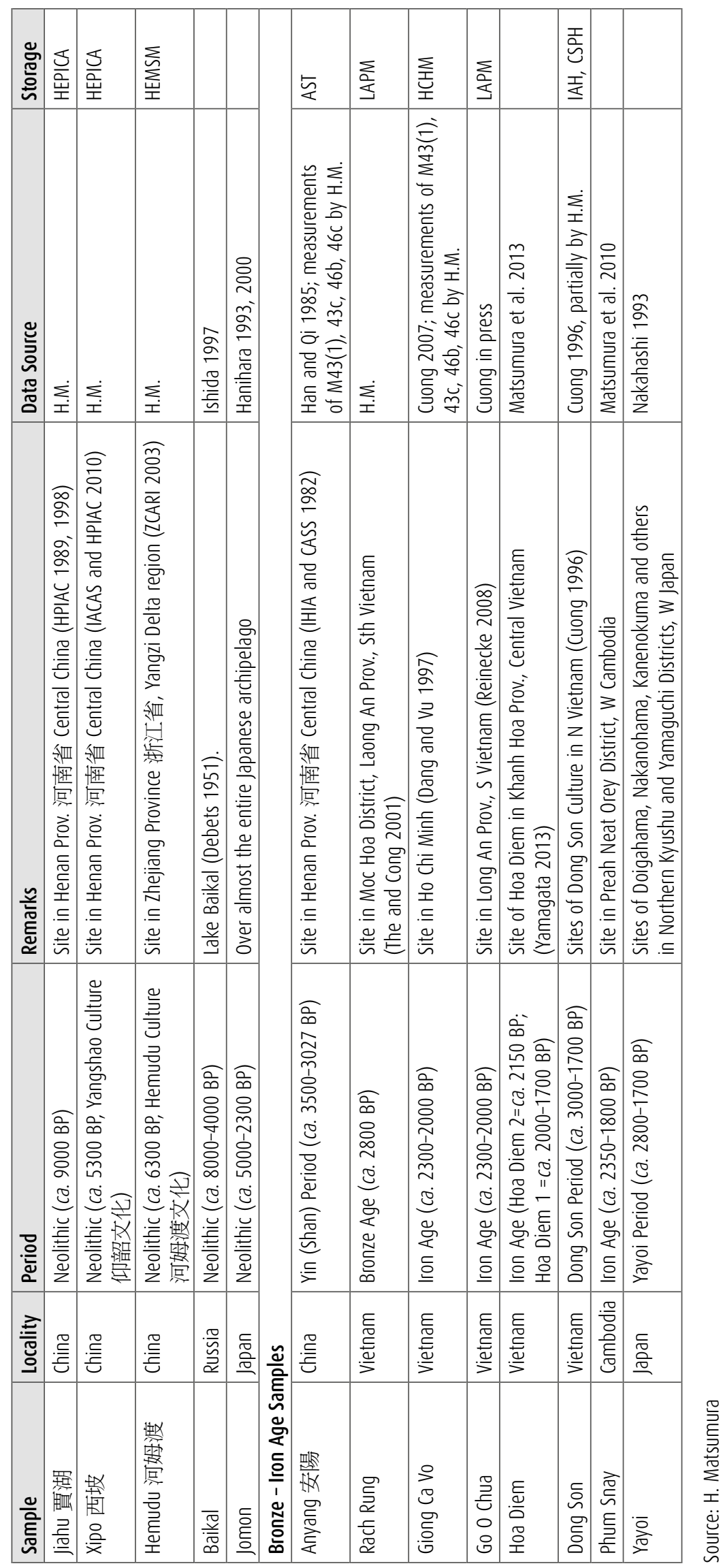



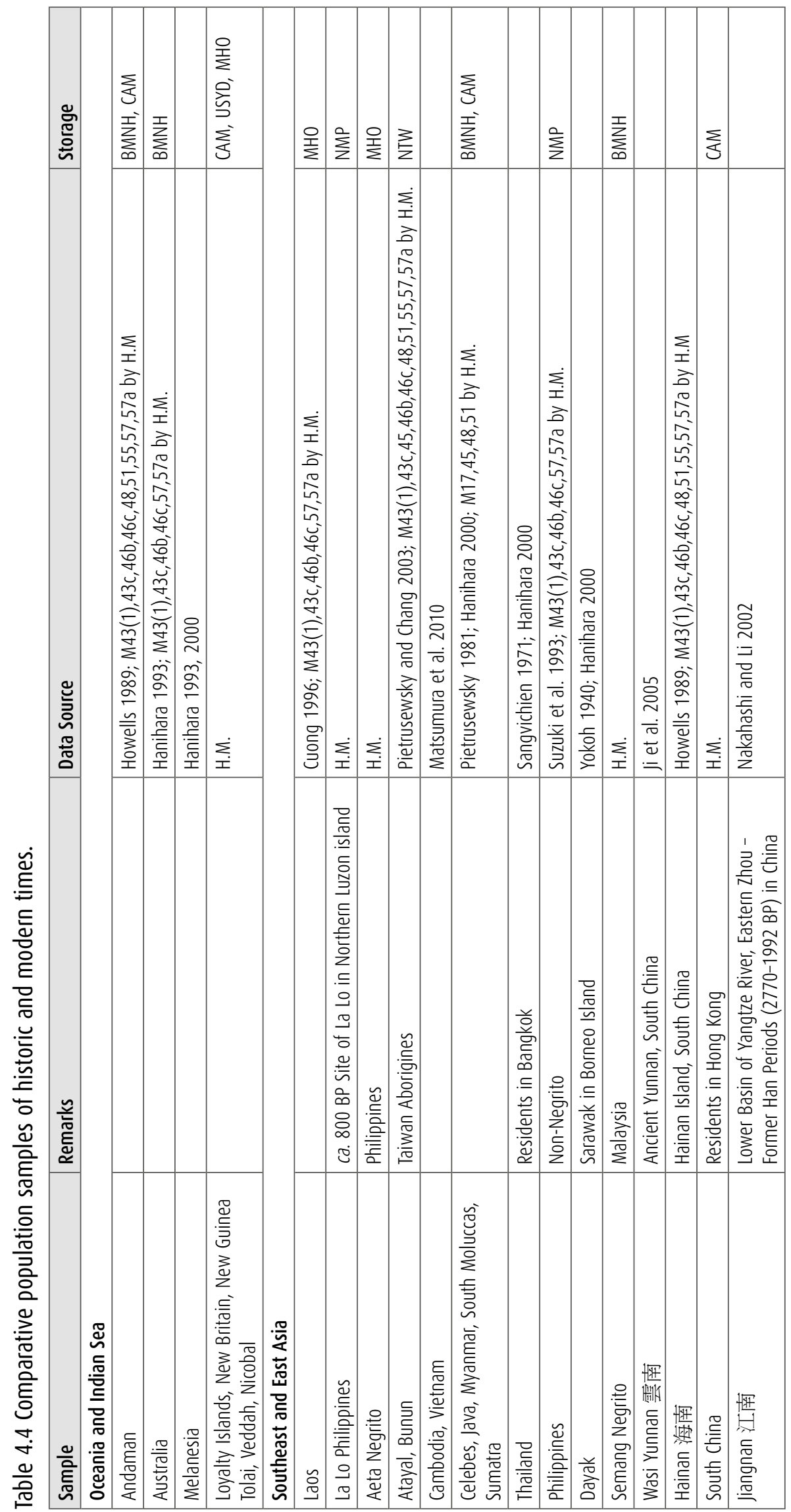


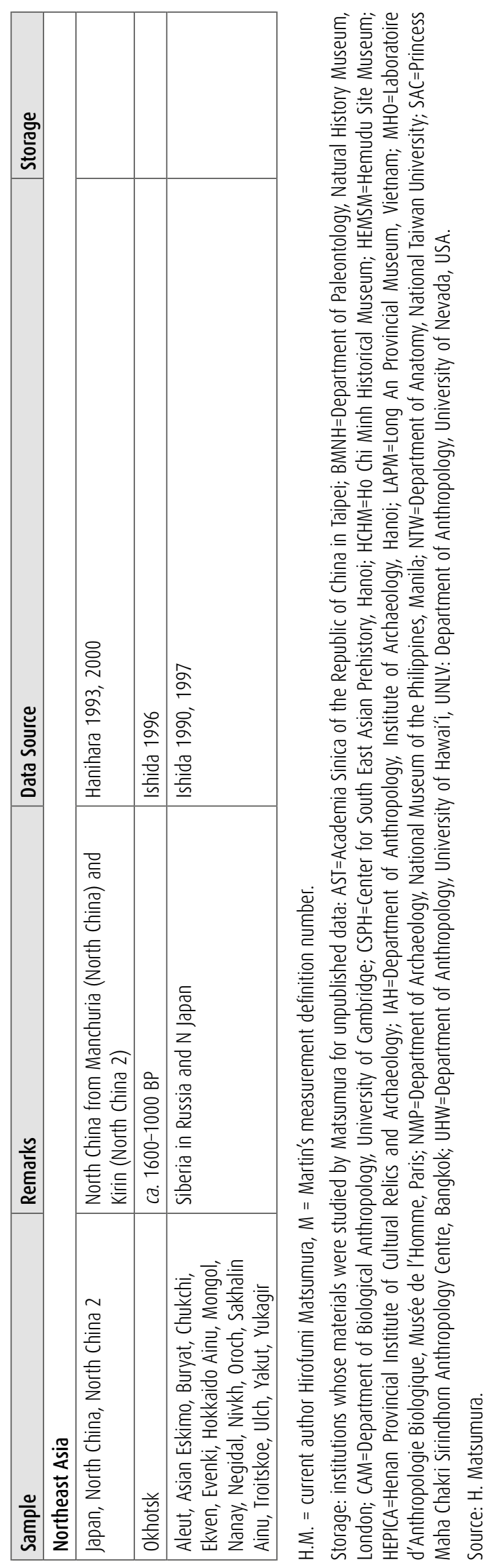




\section{Results of cranial metric analysis}

Figure 4.5 depicts the results from the neighbor-net split analysis applied to the distances of the Q-mode correlation coefficients based on 16 cranial measurements from Gaomiao and comparative population samples. The unrooted network tree diagram resulting from this analysis branches into two major clusters at the right and left sides. These include: 1) East Asians and many Southeast Asians ranging from the Neolithic to modern times; and 2) Australo-Melanesians and early Holocene Southeast Asians, including the Hoabinhian and Mesolithic (see Bellwood 2014 on the use of term 'Mesolithic' for Southern China and Northern Southeast Asian archaeology), respectively. The Gaomiao specimen branched out relatively close to the cluster consisting of Australo-Melanesian and Hoabinhian samples.

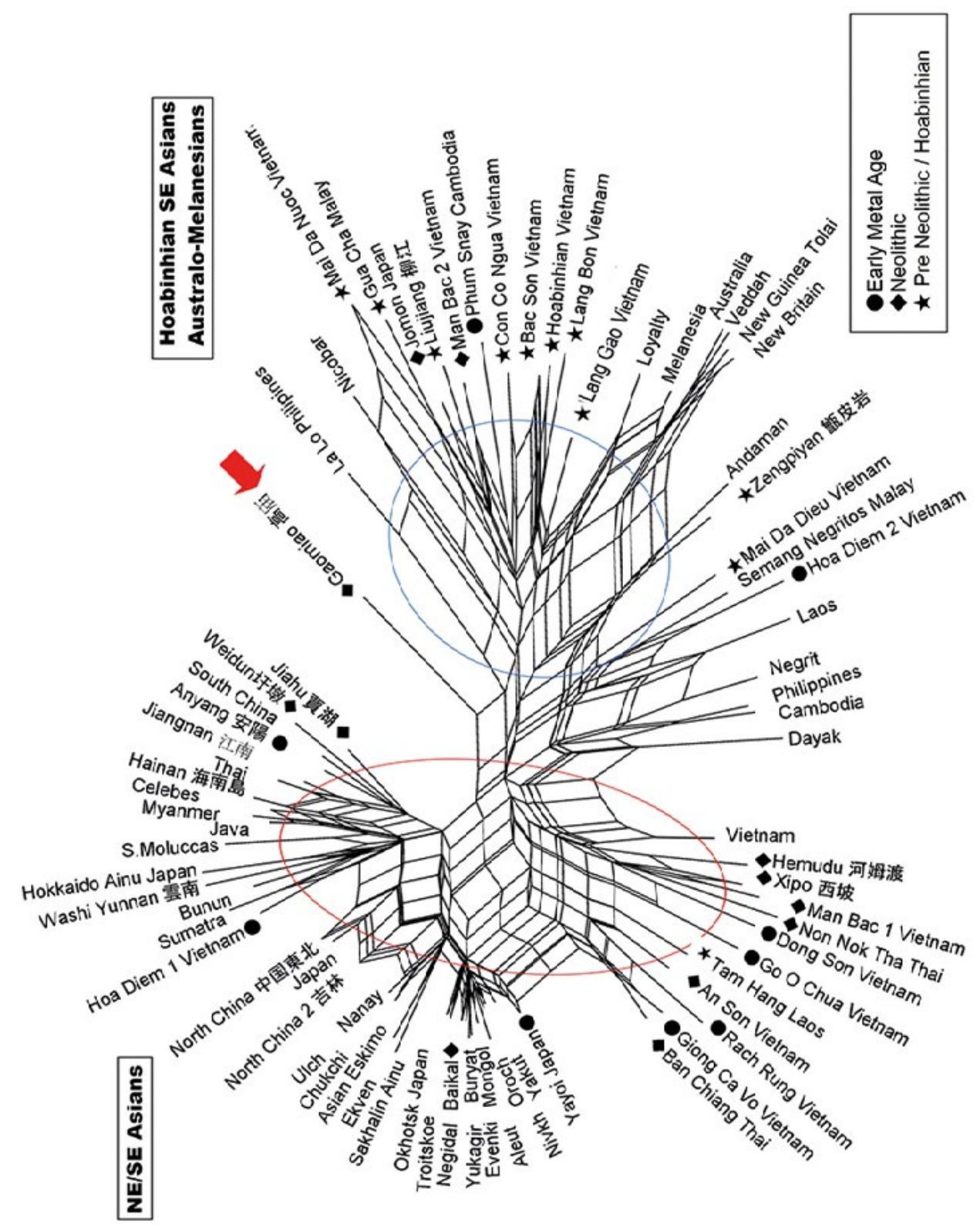

Figure 4.5 Net split tree generated from Q-mode correlation coefficients based on 16 cranial measurements.

Source: H. Matsumura. 


\section{Discussion and conclusion}

In comparing the Gaomiao specimen with ethnically, chronologically and geographically different population samples, dissimilarities from the majority of comparative East and Northeast Asian samples, including other Neolithic samples from China such as those from Jiahu (賈湖), Xipo (西坡), Hemudu (河姆渡) and Weidun (圩墩), are apparent in the cranial morphology. The interpretation of this difference is a crucial issue in the discussion of the population history of this region. With regard to Hoabinhian/Mesolithic foragers, which were widely distributed over Mainland Southeast Asia during the Late Pleistocene and early Holocene, the majority of analyses of skeletal materials have demonstrated cranial morphology with Australo-Melanesian characteristics (Callenfels 1936; Mijsberg 1940; Jacob 1967). These skeletons of the preceramic period may represent some of the early indigenous settlers of Southeast Asia who were possibly the first modern human colonisers of MSEA, and the subcontinental Sahul, who were ancestral to present-day Australo-Melanesians in the region. Based on these findings, Southeast Asia is thought to have been initially occupied by such indigenous people who later exchanged or admixed genes with immigrants from North and/or East Asia, leading to the formation of presentday populations. This is known as the 'two-layer' hypothesis, and is a common hypothesis used to explain the population history of this region. Most recent studies based on the morphological analysis of new skeletal discoveries, as well as dental characteristics, strongly support the twolayer hypothesis (Matsumura and Hudson 2005; Matsumura 2006; Matsumura et al. 2008a, 2008b, 2011a, 2011b). This hypothesis has gained theoretical support from the fields of historical linguistics and archaeology, which have linked the dispersal of language families, including Austronesian, Austroasiatic, Daic, Tai-Kadai, Miao-Yao, etc., with the expansion of rice farming societies during the Neolithic period (Bellwood 1987, 1991, 2005; Higham 1998, 2001; Bellwood and Renfrew 2003; Diamond and Bellwood 2003; Zhang and Hung 2010). These studies of historical linguistics and archeology suggest that south China was a major center of linguistic diversification and appears to have been the ultimate source of the language families.

The morphometric analysis of this early phase Gaomiao individual suggests it has cranial features more closely aligned with Hoabinhian/Mesolithic groups of MSEA than with modern East Asian and Northeast Asian populations (so-called 'Mongoloid' samples). Taking this cranial affinity into consideration, it may be concluded that the early phase Gaomiao hunter-gatherers (ca. $6500 \mathrm{BP}$ ), who inhabited the region prior to major interaction with farming communities, were less affected by substantial gene flow via diffusion from northern and eastern peripheral areas than other contemporary Neolithic Chinese such as the Jiahu (賈湖), Xipo (西坡) and Hemudu (河姆渡) peoples. It may be worth mentioning in passing that the early Holocene Zengpiyan（甑皮岩） skull from Guangxi Province is also affiliated with early indigenous aggregation (see Figure 4.5), suggesting that the Gaomiao people had genetic material inherited from such early settlers of southern China. Thus far, the long debate concerning the two-layer hypothesis has targeted the population history of Southeast Asia. Our current morphometric analyses of the Gaomiao skeleton may expand adoption of the two-layer scenario to the area of inland China by elucidating the genealogical affinity of the early indigenous populations before diffusion of the rice farming peoples phenotypically possessing Northeast Asian features into the region. 


\section{Acknowledgements}

We express sincere gratitude to Dr Wei Xing-tao (Henan Provincial Institute of Archaeology), Professor Li Xin-wei (Institute of Archaeology, Chinese Academy of Social Science in Beijing), Director Huang Wei-jin (Hemudu Museum in Zhejiang) and Professor Sun Guo-ping (Zhejiang Provincial Institute of Archaeology) for their collaboration and permission to study the Chinese Neolithic skeletal remains.

This study was supported in part by KAKENHI in 2012-2015 (nos 2347040 and 16H02527) from the Japan Society for the Promotion of Science (JSPS) and ARC Discovery Project in 20112013 (ID: DP 110101097) from the Australian Research Council (ARC) Grant Aid in Australia .

\section{References}

Bayard, D.T. 1971. Non Nok Tha: The 1968 Excavation, procedure, stratigraphy, and summary of the evidence. University of Otago Studies in Prehistoric Anthropology, vol. 4. Dunedin: University of Otago.

Bellwood, P. 1987. The prehistory of Island Southeast Asia: a multidisciplinary review of recent research. Journal of World Prehistory 1: 171-224. doi.org/10.1007/BF00975493.

- 1991. The Austronesian dispersal and the origin of languages. Scientific American 265: 88-93. doi. org/10.1038/scientificamerican0791-88.

- 2005. Examining the farming/language dispersal hypothesis in the East Asian context. In L. Sagart, R. Blench and A. Sanchez-Mazas (eds), The Peopling of East Asia: Putting Together Archaeology, Linguistics and Genetics, pp. 17-30. London: Routledge. doi.org/10.4324/9780203343685_ chapter_1.

- 2014. The human populations and archaeology of Southern China and Northern Southeast Asia: pre-Neolithic into Neolithic. Paper presented at 2014 From Matsu Archipelago to Southeast Coast of Asia: International Symposium on the Studies of Prehistoric Cultural and Physical Remains, 27-28 September 2014, Academia Sinica, Taipei.

Bellwood, P. and C. Renfrew (eds). 2003. Examining the Farming/Language Dispersal Hypothesis. McDonald Institute for Archaeological Research, Cambridge.

Bellwood, P., M. Oxenham, C.H. Bui, T.K.D. Nguyen, A. Willis, C. Sarjeant, P.J. Piper, H. Matsumura, K. Tanaka, M. Beavan, T. Higham, Q.M. Nguyen, N.K. Dan, K.T.K. Nguyen, T.H. Vo, VNB, T.K.Q. Tran, P.T. Nguyen, F. Campos, Y.I. Sato, L.C Nguyen and N. Amano. 2013. An Son and the Neolithic of Southern Vietnam. Asian Perspectives 50: 144-175.

Bräuer, G. 1988. Osteometrie. In R. Martin, and K. Knussmann (eds), Anthropologie, pp. 160-232. Stuttgart: Gustav Fisher.

Callenfels, V.S. 1936. The Melanesoid civilizations of Eastern Asia. Bulletin of the Raffles Museum 1 (Series B): 41-51.

Cuong, N.L. 1986. Two early Hoabinhian crania from Thanh Hoa province, Vietnam. Zeitschrift fur Morphologie und Anthropologie 77: 11-17.

1996. Anthropological Characteristics of Dong Son Population in Vietnam. Hanoi: Social Sciences Publishing House (in Vietnamese with an English title and summary).

- 2003. Ancient human bones in Da But Culture - Thanh Hoa Province. Khao Co Hoc (Vietnamese Archaeology) 3-2003: 66-79 (in Vietnamese with an English title and summary). 
-2006. About the ancient human bones at An Son (Long An) through the third excavation. Khao Co Hoc (Archaeology) 6-2006: 39-51 (in Vietnamese with an English title and summary).

—. 2007. Paleoanthropology in Vietnam. Khao Co Hoc (Vietnamese Archaeology) 2-2007: 23-41.

—. in press. Anthropological Study on the Origin of Vietnamese People (in Vietnamese with an English title and summary).

Dang, V.T and Q.H. Vu. 1997. Excavation of Giong Ca Vo site (Can Gio District, Ho Chi Minh City). Journal of Southeast Asian Archaeology 17: 30-44.

Debets G.F. 1951. Anthropological studies in the Kamchatka region. Trudy Institute of Ethnography, 17 (New Series): 1-263 (in Russian).

Demeter, F.T., E. Sayavongkhamdy, A.S. Patole-Edoumba, A.M. Coupey, J. Bacon, C. DeVos, B. Tougard, P. Bouasisengpaseuth, Sichanthongtip and P. Duringer. 2009. Tam Hang rockshelter: Preliminary study of a prehistoric site in northern Laos. Asian Perspectives 48: 291-308. doi. org/10.1353/asi.2009.0000.

Diamond, J. and P. Bellwood. 2003. Farmers and their languages: The first expansions. Science 300: 597-603. doi.org/10.1126/science.1078208.

Gorman, C.F. and P. Charoenwongsa. 1976. Ban Chiang: A mosaic of impressions from the first two years. Expedition 18: 14-26.

Gu, H.B. and Z.J. Zhao. 2009. Study on carbonized rice from different cultural phases in Hunan. Dongfang Kaogu 6: 358-365 (in Chinese).

Han K.X. and P.F. Qi. 1985. The study of the human bones of the middle and small cemeteries of Yin sites, Anyang. In Institute of History and Institute of Archaeology (IHIA)(eds), Contributions to the Study on Human Skulls from the Shang Sites at Anyang, pp. 50-81. Beijing: Cultural Relics Publishing House (in Chinese).

Hanihara, T. 1993. Craniofacial features of Southeast Asians and Jomonese: A reconsideration of their microevolution since the late Pleistocene. Anthropological Science 101: 25-46. doi.org/10.1537/ ase.101.25.

- 2000. Frontal and facial flatness of major human populations. American Journal of Physical Anthropology 111: 105-134. doi.org/10.1002/(SICI)1096-8644(200001)111:1<105::AIDAJPA7>3.0.CO;2-O.

He, G. 2006a. Reappearance of prehistoric religious and ritual scenario- the Neolithic Gaomiao site in Hongjiang, Hunan. Paper presented at the archaeology forum of the Chinese Academy of Social Sciences: new discoveries in Chinese archaeology in 2005, Chinese Academy of Social Science, Beijing, 10 January 2006 (in Chinese).

- 2006b. The big discovery of Hongjiang Gaomiao site in Hunan. China Cultural Relics News 6 January 2006: 1 (in Chinese).

Higham, C.F.W. 1998. Archaeology, linguistics and the expansion of the East and Southeast Asian Neolithic. In R. Blench and M. Spriggs (eds), Archaeology and Language II: Archaeological Data and Linguistic Hypotheses, pp. 103-114. London: Routledge. doi.org/10.4324/9780203202913_ chapter_3. 
2001. Prehistory, language and human biology: is there a consensus in East and Southeast Asia? In L. Jin, M. Seielstad, and C.J. Xiao (eds), Genetic, Linguistic and Archaeological Perspectives on Human Diversity in Southeast Asia, pp. 3-16. Singapore: World Scientific. doi. org/10.1142/9789812810847_0001.

Howells, W.W. 1989. Skull Shapes and the Map: Cranio-Metric Analysis in the Dispersion of Modern Homo. Papers of the Peabody Museum of Archaeology and Ethnology, vol. 79. Cambridge: Harvard University Press.

HPIAC (Henan Provincial Institute of Archaeology and Cultural Relics). 1989. Henan Wuyang Jiahu Xiangshiqi Shidai Yizhi Di Erci Zhi Di Liuci Fajue Jianbao (Excavations of the Neolithic sites at Jiahu in Wuyang, Henan [2nd-6th seasons]). Wenwu: Cultural Relics 1: 2-20 (in Chinese).

1998. Wuyang Jiahu (Jiahu Site at Wuyang). Beijing: Science Press (in Chinese).

Huard, P. and E. Saurin. 1938. État Actuel de la Craniologie Indochinoise. Bulletin du Service Géologique de l'Indochine XXV (in French).

Hudson, D.H. and D. Bryant. 2006. Application of phylogenetic networks in evolutionary studies. Molecular Biology and Evolution 23: 254-267. doi.org/10.1093/molbev/msj030.

IACAS (Institute of Archaeology, Chinese Academy of Social Science) and HPIAC (Henan Provincial Institute of Archaeology and Cultural Relics) (eds). 2010. Xipo Cemetery in Lingbao. Beijing: Cultural Relics Publishing House (in Chinese with English summary).

IACAS (Institute of Archaeology, Chinese Academy of Social Science), ATGZM (Archaeological Team of the Guangxi Zhuang Municipality), ZM (Zengpiyan Museum) and ATGC (Archaeological Team of Guilin City). 2003. Zengpiyan - a Prehistoric Site in Guilin. Archeological Monograph Series Type D no. 69. Beijing: Cultural Relics Publishing House (in Chinese with an English title and abstract).

IHIA (Institute of History and Institute of Archaeology) and CASS (Chinese Academy of Social Science) (eds). 1982. Contributions to the Study on Human Skulls from the Shang Sites at Anyang. Beijing: Cultural Relics Publishing House (in Chinese with an English summary).

Ishida, H. 1990. Cranial morphology of several ethnic groups from the Amur basin and Sakhalin. Journal of the Anthropological Society of Nippon 98: 137-148. doi.org/10.1537/ase1911.98.137.

- 1996. Metric and nonmetric cranial variation of the prehistoric Okhotsk people. Anthropological Science 104: 233-258. doi.org/10.1537/ase.104.233.

- 1997. Craniometric variation of the Northeast Asian populations. Homo 48: 106-124.

Jacob, T. 1967. Some Problems Pertaining to the Racial History of the Indonesian Region. Unpublished $\mathrm{PhD}$ dissertation, University of Utrecht, Utrecht.

Ji, X., M. Nakayama, K. Han, X. Liu, H. Liu, and O. Kondo. 2005. Unique biological affinity of the hanging coffin people in ancient China based on craniometry of two skulls from Yunnan province. Anthropological Science 113: 259-271. doi.org/10.1537/ase.040805.

Mansuy, H. and M. Colani. 1925. Contribution à l'étudede la préhistoire de l'Indochine VII. Néolithique inférieur (Bacsonien) et Néolithique supérieur dans le Haut-Tonkin. Bulletin du Service Géologique de l'Indochine 12: 1-45.

Matsumura, H. 2006. The population history of Southeast Asia viewed from morphometric analyses of human skeletal and dental remains. In M. Oxenham, and N. Tayles (eds), Bioarchaeology of Southeast Asia, pp. 33-58. Cambridge: Cambridge University Press. doi.org/10.1017/ CBO9780511584220.004. 
2011. Quantitative cranio-morphology at Man Bac. In M.F. Oxenham, H. Matsumura and N.K. Dung (eds), Man Bac: The Excavation of a Late Neolithic Site in Northern Vietnam, pp. 21-32. Terra Australis 33. Canberra: ANU E Press.

Matsumura, H. and M.J. Hudson. 2005. Dental perspectives on the population history of Southeast Asia. American Journal of Physical Anthropology 127: 182-209. doi.org/10.1002/ajpa.20067.

Matsumura, H. and M.F. Oxenham. 2013a. Eastern Asia and Japan: human biology. In I Ness (ed.), The Encyclopedia of Global Human Migration. Wiley-Blackwell. DOI: 10.1002/9781444351071. doi. org/10.1002/9781444351071.

—. 2013b. Population dispersal from East Asia into Southeast Asia: Perspectives from prehistoric human remains, in K. Pechenkina and M.F. Oxenham (eds), Bioarchaeological Perspectives on Migration and Health in Ancient East Asia, pp. 179-212. Florida: University of Florida.

- 2014. Demographic transitions and migration in prehistoric East/Southeast Asia: Through the lens of nonmetric dental traits. American Journal of Physical Anthropology 155: 45-65. doi.org/10.1002/ ajpa.22537.

.2015. Eastern Asia and Japan: human biology. In P. Bellwood, (ed.), The Global Prehistory of Human Migration, pp. 217-223 New York: Wiley-Liss.

Matsumura, H. and M. Zuraina. 1999. Metric analyses of an early Holocene human skeleton from Gua Gunung Runtuh, Malaysia. American Journal of Physical Anthropology 109: 327-340. doi. org/10.1002/(SICI) 1096-8644(199907)109:3<327::AID-AJPA4>3.0.CO;2-5.

Matsumura, H., M. Yoneda, Y. Dodo, M.F. Oxenham, N.K. Thuy, N.L. Cuong, L.M. Dung, V.T. Long, M. Yamagata, J. Sawada, K. Shinoda and W. Takigawa. 2008a. Terminal Pleistocene human skeleton from Hang Cho cave, northern Vietnam: implications for the biological affinities of Hoabinhian people. Anthropological Science 116: 135-148. doi.org/10.1537/ase.070405.

Matsumura, H., M.F. Oxenham, Y. Dodo, K. Domett, N.L. Cuong, N.K. Thuy, N.K. Dung, D. Huffer and M. Yamagata. 2008b. Morphometric affinity of the late Neolithic human remains from Man Bac, Ninh Binh Province, Vietnam: Key skeletons with which to debate the 'two layer' hypothesis. Anthropological Science 116: 135-148. doi.org/10.1537/ase.070405.

Matsumura, H., K. Domett and D. O'Reilly. 2011a. On the origin of pre-Angkorian peoples: Perspectives from cranial and dental affinity of the human remains from Iron Age Phum Snay, Cambodia. Anthropological Science 119: 67-79. doi.org/10.1537/ase.100511.

Matsumura, H., M.F. Oxenham, K.T. Nguyen, L.C. Nguyen, and K.D. Nguyen. 2011b. The population history of mainland Southeast Asia: Two layer model in the context of Northern Vietnam. In N. Enfield (ed.), Dynamics of Human Diversity: the Case of Mainland Southeast Asia, pp. 153-178. Canberra: Pacific Linguistics.

Matsumura, H., N.L. Cuong and M. Yamagata. 2013. The origin of Hoa Diem people: Perspectives from cranial and dental morphometric Analysis. In M. Yamagata, and V.T. Hoang (eds), The Excavation of Hoa Diem in Central Vietnam, pp. 241-260. Tokyo: Showa Womens University.

Matsumura, H., M.F. Oxenham and N.L. Cuong. 2015. Hoabinhian: Key Population with which to debate the peopling Southeast Asia, T. Goebel and Y. Kaifu (eds), Emergence and Diversity of Modern Human Behavior in Palaeolithic Asia, pp. 117-132. Texas: Texas A\&M University Press.

Mijsberg, W.A. 1940. On a Neolithic Paleo-Melanesian lower jaw found in kitchen midden at Guar Kepah, Province Wellesley, Straits Settlements. Proceedings of 3rd Congress of Prehistorians of the Far East, Singapore, pp. 100-118. 
Nakahashi, T. 1993. Temporal craniometric changes from the Jomon to the modern period in western Japan. American Journal of Physical Anthropology 90: 409-425. doi.org/10.1002/ajpa.1330900403.

Nakahashi, T. and M. Li (eds). 2002. Ancient People in the Jiangnan Region, China. Fukuoka: Kyushu University Press.

Nishimura, M. and N.K. Dung. 2002. Excavation of An Son: a Neolithic site in the middle reach of the Vam Co Dong River, southern Vietnam. Bulletin of the Indo-Pacific Prehistory Association 22: 101-109.

Oxenham, M.F., H. Matsumura and N.K. Dung (eds). 2011. Man Bac: The Excavation of a Late Neolithic Site in Northern Vietnam. Terra Australis 33. Canberra: ANU E Press.

Pietrusewsky, M. 1981. Cranial variation in early metal age Thailand and Southeast Asia studied by multivariate procedures. Homo 32: 1-26.

Pietrusewsky, M. and M.T. Douglas. 2002. Ban Chiang, a Prehistoric Village Site in Northeast Thailand I: The Human Skeletal Remains. Philadelphia: University of Pennsylvania, Museum of Archaeology and Anthropology.

Pietrusewsky, M. and C. Chang. 2003. Taiwan aboriginals and peoples of the Pacific-Asia region: multivariate craniometric comparisons. Anthropological Science 111: 293-332. doi.org/10.1537/ ase. 111.293 .

Reinecke, A. 2008. Briquetage und Gräber in Go O Chua (Vietnam): Zeugnisse der Prä-Funan- bis Angkor-Periode im Mekong-Delta: Zeitschrift für Archäologie Außereuropäischer Kulturen Bd. 2-2007: 395-402.

Sangvichien, S. 1971. Physical Anthropology of the skull of Thai .Unpublished PhD dissertation, Faculty of Medicine Siriraj Hospital, Mahidol University, Bangkok, no. 2514.

Sieveking, G.G. 1954. Excavations at Gua Cha, Kelantan, Part 1. Federation Museums Journal 1: 75-143.

Sneath, P.H. and R.R. Sokal. 1973. Numerical Taxonomy. San Francisco: WH Freeman and Co.

Suzuki, H., Y. Mizoguchi and E. Conese. 1993. Craniofacial measurement of artificially deformed skulls from the Philippines. Anthropological Science 101: 111-127. doi.org/10.1537/ase.101.111.

The, N.K. and D.N. Cong. 2001. Archeology in Long An Province. Long An: Long An Provincial Museum.

Thuy, N.K. 1990. Ancient human skeletons at Con Co Ngua. Khao Co Hoc 3: 37-48 (in Vietnamese with an English summary).

Woo, J. 1959. Human fossils found in Liukiang, Kwangsi, China. Vertebrata Palasiatica 3: 108-118.

Yamagata, M. and V.T. Hoang (eds). 2013. The excavation of Hoa Diem in central Vietnam. Tokyo: Showa Women's University.

Yokoh, Y. 1940. Beiträge zur kraniologie der Dajak. Japanese Journal of Medical Science, Part I Anatomy 8: $1-354$.

ZCARI (Zhejiang Cultural Relics Archaeological Research Institute). 2003. Hemudu-Xishiqishidai yizhi kaogu fajüe baogao Hemudu [Report on the Excavation of the Neolithic Hemudu Site]. Beijing: Wenwu (in Chinese).

Zhang, C. and H.-c. Hung. 2010. The emergence of agriculture in southern China. Antiquity 84(323): 11-25. doi.org/10.1017/S0003598X00099737.

- 2012. Later hunter-gatherers in Southern China, 18000-3000BC. Antiquity 86(331): 11-25. doi. org/10.1017/S0003598X00062438. 
This text is taken from New Perspectives in Southeast Asian and Pacific Prehistory, edited by Philip J. Piper, Hirofumi Matsumura and David Bulbeck, published 2017 by ANU Press, The Australian National University, Canberra, Australia. 